www.jmscr.igmpublication.org

Index Copernicus Value: 79.54

ISSN (e)-2347-176x ISSN (p) 2455-0450

crossrefDOI: https://dx.doi.org/10.18535/jmscr/v7i3.15

\title{
A Case Report of Insecticide Poisoning Treated with Methylene Blue
}

\author{
Authors \\ A. Jonathan Arland, Saravana Madhav. S, N. Vijayakumar, R. Umarani \\ Department of Medicine, Annamalai University, Rajah Muthaiah Medical College and Hospital \\ Chidambaram - 608002, India
}

Abstract
A case of insecticide poisoning resulting in methhemoglobinemia which was successfully treated with
methylene blue.
Keywords: I.V., Intravenous; MB, Methylene Blue; P.O., Oral.

\section{Introduction}

Methemoglobinemia is a condition characterised by excess amounts of abnormal haemoglobin 'methemoglobin'. Methemoglobinemia can occur due to congenital and acquired causes of which toxin mediated methemoglobinemia is one of the common causes. Here we report a case of methemoglobinemia due to insecticide ( $\mathrm{p}$ chlorantraniloprole) poisoning which was successfully treated in our ICU with methylene blue. $^{1}$

\section{Case Report}

A 33 old male presented to emergency with alleged history of consumption of an insecticide (chlorantraniliprole) mixed with alcohol. On arrival he was hypotensive, tachypneic and cyanosed. He was intubated and started on mechanical ventilation. Inotropic support with noradrenaline was commenced. There was not much improvement in oxygen saturation $\left(\mathrm{SpO}_{2}\right)$ measured by pulse oximeter.

Blood samples drawn for $\mathrm{ABG}$ were dark red colour. ABG showed normal saturation. Urine samples had a chocolate brown colour. Renal parameters were within normal limits. $\mathrm{Hb}$ at admission was $9.4 \mathrm{~g} / \mathrm{dl}$. In view of the altered colour of blood and urine and the saturation gap methhemoglobinemia was suspected. Methemoglobin level was 3.9\%.

He was treated with intravenous Inj. Methylene blue $40 \mathrm{mg}$ in $100 \mathrm{ml}$ with normal saline over 20 min. 12 hours later his oxygen saturation and blood pressure improved. He was then weaned off from the ventilator and inotrope support withdrawn. He was then treated with other supportive medications and vitamin $\mathrm{C}$ twice daily. He was discharged on the $14^{\text {th }}$ day.

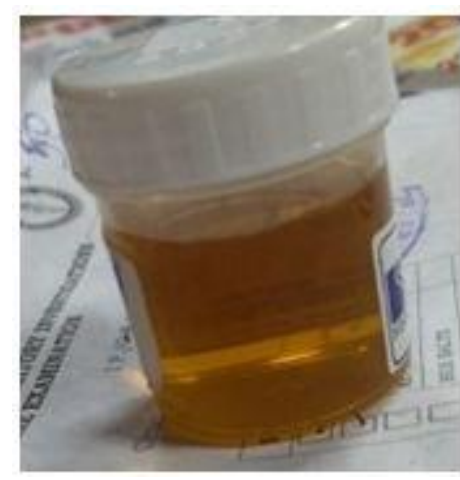

Chocolate Brown Urine 


\section{Discussion}

Methemoglobinemia is a condition in which the oxidised form of haemoglobin $(\mathrm{Hb})$, the ferrous $(\mathrm{Fe} 2+)$ iron is transformed into ferric $(\mathrm{Fe} 3+)$ state, resulting in impaired oxygen delivery to the tissues and causes brownish discolouration of blood. It can be potentially fatal if untreated. Drugs and toxins are the common causes of acquired methemoglobinemia. ${ }^{2-3}$ Recommended treatment for methemoglobinemia is based on the principle of decontamination and the specific antidotes are methylene blue and ascorbic acid. Methylene blue is a heterocyclic aromatic molecule with the chemical formula $\mathrm{C} 16 \mathrm{H} 18 \mathrm{CIN} 3 \mathrm{~S}$. Methylene blue is metabolized to leucomethylene blue by nicotinamide adenine dinucleotide phosphate and excreted primarily in urine, turning the urine a bluegreen color. A small portion of the drug is also excreted unchanged in the urine. In cases of G6PD deficiency the utility of methylene shoud be catious as this can result in hemolytic anemia. This occurs due to decreased ability to reduce methylene blue into its metbolites. ${ }^{4}$ The terminal half-life of MB is 5.25 hours. The clinical applications of methylene blue includes usage of physicians as a dye in medical procedures i.e it is used when urological surgery is performed as a tool to locate the gland. The vasoconstrictive efect of $\mathrm{MB}$ occurs only during cases of nitric oxide (NO) upregulation. ${ }^{(8,9,10)}$

\section{Dosage of methylene blue in different clinical conditions ${ }^{(7)}$}

\begin{tabular}{|c|c|}
\hline Therapeutic indication & Dosage of methylene blue \\
\hline Inherited methemoglobinemia & 1 X 50-250 mg/day (for a lifetime) (Cawein et al., 1964) \\
\hline Acute methemoglobinemia & $1-2 X_{-} 1.3 \mathrm{mg} / \mathrm{kg}$ (i.v. over 20 minutes) \\
\hline Ifosfamide-induced neurotoxicity & 4 X50 mg/day p.o. or i.v. (Pelgrims et al., 2000) \\
\hline Vasoplegic adrenaline-resistant shock & $\begin{array}{l}\text { 200mg i.v over } 1 \text { hour followed by infusion } \\
(0.25-2 \mathrm{mg} / \mathrm{kg} / \text { hour) (Warth et al.,2009) }\end{array}$ \\
\hline $\begin{array}{l}\text { Prevention of urinary tract infections in } \\
\text { elderly patients }\end{array}$ & Orally $3 \mathrm{X} 65 \mathrm{mg} /$ day \\
\hline Alzheimer's disease & $\begin{array}{l}3 \mathrm{X} 60 \mathrm{mg} / \text { day (Rember }{ }^{\mathrm{TM}} \text { according to Wischik } \\
2008)\end{array}$ \\
\hline Pediatric malaria & $2 \mathrm{X} 12 \mathrm{mg} / \mathrm{kg}$ p.o. for 3 days \\
\hline
\end{tabular}

Methylene blue is the antidote of choice for acquired methemoglobinemia. There are several contraindications for methylene blue administration. This includes patients taking serotonin reuptake inhibitors ${ }^{(5,6)}$ and persons with certain types of hereditary glucose-6-phosphate dehydrogenase deficiency (G6PD deficiency). This enzyme provides antioxidant-reducing equivalents in the form of NADPH.

It is an exogenous co-factor which greatly accelerates the NADPH-dependant methemoglobin reductase system and is indicated if the methemoglobin levels are more than $20 \%$ or if the patient is symptomatic. It is administered intravenously at $1-2 \mathrm{mg} / \mathrm{kg}$ (up to $50 \mathrm{mgdose}$ in adults) as a $1 \%$ solution over 5 to 10 minutes with a repeat in one hour if necessary.

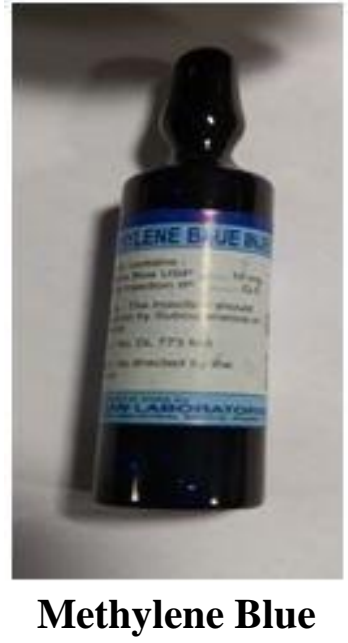

To conclude early recognition of methhemoglobinemia and prompt treatment with methylene blue and ascorbic acid is crucial in improving outcomes of certain poisoning. 


\section{References}

1. Gupta G.Poddar B, Parmur V. Acute nitrobenzene poisoning.

2. Dutta R, Dube S K, Mishra L D, Singh A $\mathrm{P}$, Acute methemoglobinemia.

3. Geroge $T$ ShaikhAI, Thomas L, Kundavaram AP, Severe Methemoglobinemia due to insecticide poisoning.

4. Chongtham D S, Phurailatpam J, Singh M $\mathrm{M}$, Singh $\mathrm{T} \mathrm{R}$, Methemoglobinemia in Nitrobenzene poisoning

5. Khavandi, A., Whitaker, J., Gonna, H., 2008. Serotonin toxicity precipitated by concomitant use of citalopram and methylene blue. Med. J.Aust. 189, 534535.

6. Ramsay, R.R., Dunford, C., Gillman, P.K., 2007. Methylene blue and serotonin toxicity: inhibition of monoamine oxidase A (MAO A) confirms a theoretical prediction. Br. J. Pharmacol. 152, 946-951.

7. Schirmer,R.Heiner,et al. , 2011. Lest we forget you Methylene Blue. Neurobiology of Aging, Vol.32, no.12, 2011.

8. McDonagh EM, Bautista JM, Youngster I, Altman RB, Klein TE. Pharm GKB summary: methylene blue pathway. Pharmacogenet Genomics 2013;23:498508

9. Faber P, Ronald A, Millar BW. Methylthioninium chloride: pharmacology and clinical applications with special emphasis on nitric oxide mediated vasodilatory shock during cardiopulmonary bypass. Anaesthesia 2005;60:575-87

10. Peter C, Hongwan D, Küpfer A, Lauterburg BH. Pharmacokinetics and organ distribution of intravenous and oral methylene blue. Eur J Clin Pharmacol 2000; 56:247-50. 